\section{ABCS}

How to cite this article: Fernandez,

Fernandez. Knowledge of people in the East London District of South Africa about Coronavirus SARS-CoV-2: an online survey. ABCS Health Sci. 2021;46:e021230. https:// doi.org/10.7322/abcshs.2021094.2005

Received: Apr 26, 2021

Revised: Aug 26, 2021

Approved: Aug 31, 2021

Corresponding author: Simon Christopher Fernandez - Faculty of Science, Engineering and Technology, Department of Applied Informatics and Mathematical Sciences, Walter Sisulu University - East London,

South Africa -

E-mail:wsusimon@gmail.com

Declaration of interests: Nothing to declare

This is an open access article distributed under the terms of the Creative Commons Attribution License

(C2021 The authors

\title{
Knowledge of people in the East London District of South Africa about Coronavirus SARS-CoV-2: an online survey
}

\author{
Simon Christopher Fernandez ${ }^{1}$, John Percival Fernandez ${ }^{2}$ \\ ${ }^{1}$ Department of Applied Informatics and Mathematical Sciences, Faculty of Science, Engineering and \\ Technology, Walter Sisulu University (WSU) - East London, South Africa \\ 2Department of Tourism, Hospitality \& Sports Management, Faculty of Business Sciences, Walter \\ Sisulu University (WSU) - East London, South Africa
}

\begin{abstract}
Introduction: World Health Organization declared Coronavirus SARS-CoV-2 a pandemic after two months of its propagation in China. The lack of coordination among people about the new Coronavirus threat is evident mainly due to the dearth of knowledge. Objective: To assess the knowledge of people in the East London district of South Africa about Coronavirus SARS-CoV-2. Methods: The study was anchored on a quantitative method approach and adopted a descriptive research design. The sample consisted of 160 adults. Using the virtual snowball sampling technique, people who were 18 years and above of age and can read English were selected for the online survey. The data were collected using a 3-point Likert scale questionnaire which was uploaded in Google Form. Data were analyzed using descriptive and inferential statistics. Results: The majority of the participants knew the myths and facts about the news. They were aware that wearing a face mask prevents Coronavirus transmission, drinking liquor and using hand dryers would not kill the virus. Some people were not sure whether eating garlic or rinsing the nose regularly with saline water would help to prevent from being affected by Coronavirus. The findings also showed that there was a significant difference $(p<0.05)$ among different age groups of people on their knowledge about the Coronavirus. Conclusion: By comparing the overall findings with the facts issued by World Health Organization, people in the East London district of South Africa had sound knowledge about Coronavirus SARS-CoV-2 on its transmission and what preventive measures should be taken.
\end{abstract}

Keywords: Knowledge; Coronavirus; COVID-19; World Health Organization; South Africa.

\section{INTRODUCTION}

The origin of COVID-19 due to Coronavirus was in Wuhan city of central Hubei province in China where the first case of it was reported in December $2019^{1}$. World Health Organization $(\mathrm{WHO})^{2}$ together with the Chinese government worked with the help of some etiological agents and realized that it was a new virus which was named Coronavirus SARS-CoV-2. 
On $11^{\text {th }}$ January 2020, a 61-year-old man who had contact with the seafood market died due to this new Coronavirus ${ }^{3}$. Thereafter, within a short time, the Coronavirus was spreading all over the world rapidly ${ }^{4}$. On $11^{\text {th }}$ February 2020, WHO declared Corona Virus as a serious disease and named it COVID-195. As the new Coronavirus spread to almost 114 countries by $11^{\text {th }}$ March 2020, WHO announced COVID-19 as a pandemic ${ }^{5}$.

Due to the threat of Coronavirus SARS-CoV-2 globally, online courses had been started to give awareness and knowledge to the health professionals about Coronavirus 5 . Provinces that cannot provide better health systems were protected by raising huge funds from all over the globe and setting up Strategic Preparedness and Response Plan. The main aim was to lower down the spread of the virus, take necessary steps to prevent the disease, keep social distancing and provide awareness and knowledge about SARSCov-2. Moreover, WHO mainly concentrated on saving the lives of people affected with this virus by developing easy-to-apply diagnostics, hurrying up delivering existing medicines and preventing the transmission of the disease ${ }^{5}$.

To limit the transmission, most of the countries have decided to go on lock-down which has made a serious crisis in the global economy. The majority of the companies insisted their employees to work from home and all kinds of institutions were closed until further notice. Adolescents were stressed due to the uncertainty and adjournment of examinations ${ }^{6}$.

As the death rates in most of the countries were increasing due to COVID -19, it was causing fear, confusion and fretfulness among common people. WHO helps people to come out of the fear and anxiety they have about COVID-19 by providing expert guidance and clearing their doubts ${ }^{5}$. As no medicine has yet been found to cure COVID-19, many myths are widely spreading among the people and facts are changing on how to handle this disease. Furthermore, people are spreading false news about the Coronavirus through social media rapidly. To clear all confusions and misunderstandings, WHO provides authentic information and myth busters in its websites ${ }^{5}$.

After all, on $14^{\text {th }}$ February 2020, the African continent's first positive case with SARS-Cov-2 was reported in Egypt ${ }^{7}$. Thereafter, 52 countries in the African continent had reported cases. $\mathrm{WHO}^{7}$ stressed that government must ensure that they have adequate resources to prevent COVID-19. WHO along with governments of African countries started working together to increase their capacities in critical areas such as contact tracing, surveillance, isolation wards and laboratory capacity. Many countries such as Nigeria, Egypt, Tunisia, Kenya, Morocco, Ethiopia and Ghana have extended their national testing units to labs with decentralized testing facility ${ }^{7}$.

On $5^{\text {th }}$ March 2020, a national public health institute of South Africa reported the first infected case of Coronavirus in South Africa on a 38-year-old male who had traveled to Italy ${ }^{8}$.
President of South Africa had announced a nationwide lockdown for three weeks which started from $26^{\text {th }}$ March 2020 with strict limitations on traveling and movement ${ }^{9}$. As of $29^{\text {th }}$ May 2020, the COVID-19 related deaths in South Africa have reached to $611^{10}$.

The lack of coordination among people about the new Coronavirus threat is evident ${ }^{11}$ which is mainly due to the dearth of knowledge. The people need to have adequate knowledge to tackle the pandemics ${ }^{12,13}$. Therefore, understanding and assessing the knowledge among people and social demographic groups about Coronavirus is a vital factor to be studied. Moreover, to the best of researchers' knowledge, no remarkable previous studies are detecting the degree of knowledge of people in South Africa on Coronavirus. The results of this study are expected to provide information that is beneficial to the government officials and Health department to understand the level of knowledge of the public about Coronavirus.

This may help them to act upon what further types of awareness and precautionary measures are to be delivered to the public. As such, assessing the knowledge among people in the East London district in South Africa about the new Coronavirus is a worthy problem for investigation.

\section{Purpose of the Study}

The purpose of this study was to assess the knowledge of people in the East London district of South Africa about Coronavirus SARS-Cov-2. Therefore, this study was guided by the following research questions: 1) To what extent do the people in the East London district of South Africa have knowledge about Coronavirus? 2) Are there any differences between age groups of people on their knowledge about Coronavirus?

\section{METHODS}

\section{Research Approach and Design}

The study was anchored on a quantitative method approach and adopted a descriptive research design as it aids to recapitulate the characteristics and measure the knowledge of participants in different groups.

\section{Study site, Sample and Sampling Technique}

The sample consisted of 160 adults located in East London city in the Eastern Cape province of South Africa. Using the virtual snowball sampling technique, people who were 18 years old and above who can read English were selected for the survey.

\section{Data Collection Instrument}

The researchers developed the questions which were entered into Google Form to conduct the online survey. The first page of the questionnaire contained the description of the study and 
informed consent. The participants were directed to answer the demographic questions (gender and age group) if they accept to take part in the survey. A 3-point Likert-scale questionnaire was used to collect the core data. There were 14 items in the scale that has different levels such as "Agree", "Not sure" and "Disagree". The scale was validated by a few experts who were in the research field to check the content validity.

\section{Ethical Clearances}

Ethical permissions were received from the university where the researchers were working and from the Metropolitan Municipality of East London to conduct the study in the areas under the municipality. Furthermore, ethical concerns including anonymity and confidentiality were explained on the first page of the questionnaire. By participating in this study, the participants declared that they were satisfied with the ethical concerns and gave consent to take part in the survey.

\section{Data collection}

After the questionnaire was loaded in Google Forms, the uniform resource locator (URL) of the questionnaire was sent to the people in the researchers' contact list who were in East London city through Facebook, WhatsApp and email. The researchers encouraged the participants to forward the URL to their friends and families who were in the East London district. By clicking on the URL, the participants were navigated to the first page where the description of the survey and informed consent were available. The data collection started on $27^{\text {th }}$ July 2020 at 12.00 AM and ended on $21^{\text {st }}$ August 2020 at 11.59 PM.

\section{Data analysis}

Descriptive analysis and inferential analysis (Analysis of Variance) were executed in Statistical Package for Social Sciences (Version 26) to analyze the quantitative data.

\section{RESULTS}

Table 1 shows the demographic information of participants. It indicates that there were $44.4 \%$ male respondents and $55.6 \%$ female respondents. A total of $38.8 \%$ of the participants who responded to the survey were in the age group of 18-25 and 26-35 each. Around $13.1 \%$ and $6.3 \%$ of the participants were in the age group of 36-45 and 46-55 respectively. About $1.8 \%$ of them were in the age group of $56-65$. Furthermore, only $1.2 \%$ of the senior citizens (above 65) responded to the survey.

Table 2 shows the knowledge of people about Coronavirus SARS-Cov-2. From Table 2, it was observed that $82.5 \%$ of the people agreed wearing a face mask is an effective way to prevent Coronavirus transmission (item 1). Additionally, $72.5 \%$ of the people disagreed on item 2 that drinking liquor kills the virus. Around $78.7 \%$ of the people disagreed that drinking methanol, ethanol or bleach kills Coronavirus (item 3). It can be seen that $31.9 \%$ of the people agreed that eating garlic helps to prevent Coronavirus infection (item 4). Around $41.9 \%$ of them were indeterminate. It was observed that $80 \%$ of the people agreed that eating garlic helps to boost immunity (item 5). While $65 \%$ of the people disagreed that HIV drugs can be used as a treatment for Coronavirus infection (item 6), 32.5\% were indeterminate. Around $23.9 \%$ of the people agreed that antibiotics can be used as a treatment for Coronavirus infection (item 7). About $32.1 \%$ of the people disagreed and $44 \%$ were not sure and one person did not answer. When $48.8 \%$ of the people disagreed that there are medicines to cure Coronavirus infection (item 8), 35.6\% were indecisive. It was observed that $72.5 \%$ of the people disagreed that hand dryer kills the Coronavirus (item 9). While $47.8 \%$ of the people disagreed on item 10 that rinsing the nose regularly with saline water helps to prevent the Coronavirus infection, $40.9 \%$ of them were uncertain and one person did not answer. It can be seen that $68.8 \%$ of the people agreed that Coronavirus can be transmitted anywhere regardless of climate (item 11). While $50.9 \%$ of the people disagreed that taking a hot bath prevents Coronavirus infection (item 12), 27\% were indeterminate and one person did not answer. About $62.5 \%$ of the people disagreed that holding breath for 10 seconds or more without coughing means you are free from Coronavirus (item 13). Furthermore, $91.3 \%$ of the people disagreed on item 14 that once you are affected with Coronavirus, then you cannot recover from it.

A one-way between-groups analysis of variance was conducted to explore the impact of age on levels of scores. The dependent variable was the total score of different items that people have recorded

Table 1: Demographic information of participants

\begin{tabular}{|c|c|c|c|}
\hline Demographic variables & Description & Total & Percentage \\
\hline \multirow{2}{*}{ Gender } & Male & 71 & $44.4 \%$ \\
\hline & Female & 89 & $55.6 \%$ \\
\hline \multirow{6}{*}{ Age } & $18-25$ & 62 & $38.8 \%$ \\
\hline & $26-35$ & 62 & $38.8 \%$ \\
\hline & $36-45$ & 21 & $13.1 \%$ \\
\hline & $46-55$ & 10 & $6.3 \%$ \\
\hline & $56-65$ & 3 & $1.8 \%$ \\
\hline & Above 65 & 2 & $1.2 \%$ \\
\hline
\end{tabular}


Table 2: Knowledge of people about Coronavirus

\begin{tabular}{|c|c|c|c|c|c|}
\hline No & ITEM & Agree & Not Sure & Disagree & Total Answered \\
\hline 1 & $\begin{array}{l}\text { Wearing a face mask is an effective way to } \\
\text { prevent Coronavirus transmission }\end{array}$ & $\begin{array}{c}132 \\
(82.5 \%)\end{array}$ & $\begin{array}{c}22 \\
(13.7 \%)\end{array}$ & $\begin{array}{c}6 \\
(3.8 \%)\end{array}$ & $\begin{array}{c}160 \\
(100 \%)\end{array}$ \\
\hline 2 & Drinking liquor kills Coronavirus & $\begin{array}{c}8 \\
(5 \%)\end{array}$ & $\begin{array}{c}36 \\
(22.5 \%)\end{array}$ & $\begin{array}{c}116 \\
(72.5 \%)\end{array}$ & $\begin{array}{c}160 \\
(100 \%)\end{array}$ \\
\hline 3 & Drinking methanol, ethanol or bleach kills Coronavirus & $\begin{array}{l}3 \\
(1.9 \%)\end{array}$ & $\begin{array}{c}31 \\
(19.4 \%)\end{array}$ & $\begin{array}{c}126 \\
(78.7 \%)\end{array}$ & $\begin{array}{c}160 \\
(100 \%)\end{array}$ \\
\hline 4 & Eating garlic helps to prevent Coronavirus transmission & $\begin{array}{c}51 \\
(31.9 \%)\end{array}$ & $\begin{array}{c}67 \\
(41.9 \%)\end{array}$ & $\begin{array}{c}42 \\
(26.2 \%)\end{array}$ & $\begin{array}{c}160 \\
(100 \%)\end{array}$ \\
\hline 5 & Eating garlic helps to boost immunity & $\begin{array}{c}128 \\
(80 \%)\end{array}$ & $\begin{array}{c}30 \\
(18.8 \%)\end{array}$ & $\begin{array}{c}2 \\
(1.2 \%)\end{array}$ & $\begin{array}{c}160 \\
(100 \%)\end{array}$ \\
\hline 6 & $\begin{array}{l}\text { HIV drugs can be used as a treatment } \\
\text { for Coronavirus infection }\end{array}$ & $\begin{array}{c}4 \\
(2.5 \%)\end{array}$ & $\begin{array}{c}52 \\
(32.5 \%)\end{array}$ & $\begin{array}{c}104 \\
(65 \%)\end{array}$ & $\begin{array}{c}160 \\
(100 \%)\end{array}$ \\
\hline 7 & $\begin{array}{l}\text { Antibiotics can be used as a treatment } \\
\text { for Coronavirus infection }\end{array}$ & $\begin{array}{c}38 \\
(23.9 \%)\end{array}$ & $\begin{array}{c}70 \\
(44 \%)\end{array}$ & $\begin{array}{c}51 \\
(32.1 \%)\end{array}$ & $\begin{array}{c}159 \\
(100 \%)\end{array}$ \\
\hline 8 & There are medicines to cure Coronavirus infection & $\begin{array}{c}25 \\
(15.6 \%)\end{array}$ & $\begin{array}{c}57 \\
(35.6 \%)\end{array}$ & $\begin{array}{c}78 \\
(48.8 \%)\end{array}$ & $\begin{array}{c}160 \\
(100 \%)\end{array}$ \\
\hline 9 & Hand dryer kills the Coronavirus & $\begin{array}{c}7 \\
(4.4 \%)\end{array}$ & $\begin{array}{c}37 \\
(23.1 \%)\end{array}$ & $\begin{array}{c}116 \\
(72.5 \%)\end{array}$ & $\begin{array}{c}160 \\
(100 \%)\end{array}$ \\
\hline 10 & $\begin{array}{l}\text { Rinsing the nose regularly with saline water } \\
\text { helps to prevent the Coronavirus infection }\end{array}$ & $\begin{array}{c}18 \\
(11.3 \%)\end{array}$ & $\begin{array}{c}65 \\
(40.9 \%)\end{array}$ & $\begin{array}{c}76 \\
(47.8 \%)\end{array}$ & $\begin{array}{c}159 \\
(100 \%)\end{array}$ \\
\hline 11 & $\begin{array}{l}\text { Coronavirus can be transmitted } \\
\text { anywhere regardless of climate }\end{array}$ & $\begin{array}{c}110 \\
(68.8 \%)\end{array}$ & $\begin{array}{c}28 \\
(17.5 \%)\end{array}$ & $\begin{array}{c}22 \\
(13.7 \%)\end{array}$ & $\begin{array}{c}160 \\
(100 \%)\end{array}$ \\
\hline 12 & Taking a hot bath prevents Coronavirus transmission & $\begin{array}{c}35 \\
(22 \%)\end{array}$ & $\begin{array}{c}43 \\
(27 \%)\end{array}$ & $\begin{array}{c}81 \\
(50.9 \%)\end{array}$ & $\begin{array}{c}159 \\
(100 \%)\end{array}$ \\
\hline 13 & $\begin{array}{l}\text { Holding breath for } 10 \text { seconds or more without coughing } \\
\text { means you are free from Coronavirus infection }\end{array}$ & $\begin{array}{c}34 \\
(16.3 \%)\end{array}$ & $\begin{array}{c}26 \\
(21.3 \%)\end{array}$ & $\begin{array}{c}100 \\
(62.5 \%)\end{array}$ & $\begin{array}{c}160 \\
(100 \%)\end{array}$ \\
\hline 14 & $\begin{array}{l}\text { Once you are infected with Coronavirus, } \\
\text { then you cannot recover from it }\end{array}$ & $\begin{array}{c}4 \\
(2.5 \%)\end{array}$ & $\begin{array}{c}10 \\
(6.2 \%)\end{array}$ & $\begin{array}{c}146 \\
(91.3 \%)\end{array}$ & $\begin{array}{c}160 \\
(100 \%)\end{array}$ \\
\hline
\end{tabular}

on their knowledge about Coronavirus. Participants were divided into six groups according to their age (Group 1: 18-25 years; Group 2: 26-35 years; Group 3: 36-45 years; Group 4: 46-55 years; Group 5: 56-65 years and Group 6: Above 65 years). As Sig. value in Levene's test was greater than 0.05 , the assumption of homogeneity of variance was not violated. There was a statistically significant difference at the $p<0.05$ level in scores for the six age groups: $F(5,154)$ $=2.932, p=0.015$. Post-hoc comparisons using the Tukey HSD test indicated that the mean score for Group $1(\mathrm{M}=29.71, S D=4.358)$ was significantly different from Group $2(M=31.94, S D=3.088)$. Group $3(M=30.67, S D=3.337)$, Group $4(M=33, S D=3.399)$, Group $5(M=30.67, S D=2.309)$ and Group $6(M=31.50, S D=4.950)$ did not differ significantly from any of the groups.

\section{DISCUSSION}

The majority of the people believed that wearing a face mask was an effective way to prevent the transmission of Coronavirus (item 1 ). $\mathrm{WHO}^{14}$ highly recommends people to wear masks when they go out of the house, when they care for an infected person at home, even when doctors go for ward rounds where there are no infected COVID-19 patients. In comparison with a study conducted by Manabe et al. ${ }^{15}$ on wearing a mask to prevent avian influenza (H5N1) virus infection in Vietnam, the knowledge of participants in this study was good. This knowledge of participants in the current study could be mainly because of the lockdown and its regulations that were implemented by the South African government.

The survey responses revealed that people did not believe that drinking liquor kills Coronavirus (item 2). $\mathrm{WHO}^{16}$ avers that consumption of any kind of alcohol does not protect you against COVID-19 and it can lead the person to a dangerous situation. A previous study conducted by Nahar et al. ${ }^{17}$ on the knowledge of residents in Bangladesh about the Nipah virus shows that only $6 \%$ of the residents did not consume raw sap as they were aware that sap contains the virus and drinking it can even lead to death. This is probably due to the regular updates and information through television and newspaper.

Most of the people in the current study knew that drinking methanol, ethanol or bleach will not kill Coronavirus (item 3). $\mathrm{WHO}^{16}$ indicates that COVID-19 cannot be cured by drinking these chemical products such as methanol, ethanol or bleach. A study conducted by Aghababaeian et al. ${ }^{18}$ on the outbreaks of methanol in Iran shows that many people were hospitalized and died by drinking methanol. Trew ${ }^{19}$ states that hundreds of Iranians died by consuming methanol amid fake reports that it will cure COVID-19 which can be considered as the lack of their knowledge. The good knowledge among South Africans about Coronavirus could be the main reason for not drinking this toxic substance. 
Most of the participants were uncertain on item 4 which is eating garlic helps to prevent Coronavirus infection. According to the researchers of the current study, this could be because of little awareness messages shown in public media. $\mathrm{WHO}^{16}$ states that eating garlic cannot be considered as a remedy as there are inadequate evidence to claim that eating garlic can protect people from the novel Coronavirus. A previous study conducted by Liu et al. ${ }^{20}$ in China shows that intake of garlic by a large number of patients was inversely associated with liver cancer.

In terms of participants' belief in immunity, the high majority of the people believe that immunity can be boosted by eating garlic (item 5). A study by Arreola et al. ${ }^{21}$ reveals that garlic can be used to enhance immunity corroborating our results, differently from those in a study conducted by Alyami et al. ${ }^{22}$ in Saudi Arabia found that only a minority of the residents believe that intake of garlic will help to boost the immunity. On this item, the knowledge of South Africans was better compared with the knowledge of residents in Saudi Arabia.

The study found that most of the participants believed that HIV drugs cannot be used as a treatment for Coronavirus infection (item 6). $\mathrm{WHO}^{23}$ avows that no evidence has been not yet found to use HIV drugs as a medicine to cure COVID-19.

The majority of the people were indeterminate on item 7 that antibiotics can be used as a treatment for Coronavirus infection. This could be because of the less general knowledge they have in the medical field. $\mathrm{WHO}^{16}$ affirms that no viruses can be treated by using antibiotics. Hoxha et al. ${ }^{24}$ conducted a study to find out the knowledge of pharmacists in Albania and found that only $13 \%$ indicated the main drawback that antibiotics are not effective against viruses.

While only $48.8 \%$ of the people stated that there are no medicines developed yet to cure Coronavirus infection (item 8), 35.6\% were indecisive. According to the view of the researchers, people were indecisive mainly because of fake news. Every individual should be updated with the new knowledge on the novel disease in order to take precautions especially when a pandemic situation arises. $\mathrm{WHO}^{16}$ articulates that no medications can be recommended yet to treat Coronavirus infection. The majority of the respondents who participated in a similar survey conducted by Iliyasu et al. ${ }^{25}$ to assess the knowledge of adults in Nigeria on Ebola virus disease indicates that there is no treatment for Ebola. Therefore, the findings of the current study showed that the knowledge of people in South Africa is lower compared with people in Nigeria.

Most of the participants in this study disagreed on item 9 that hand dryer kills the Coronavirus. $\mathrm{WHO}^{16}$ indicates that hand dryers are ineffective in killing the Coronavirus. Narayana et al. ${ }^{26}$ found that the public in India had a perception that hand dryers cannot kill the virus.

In this study, less than one third of the people believed that rinsing the nose regularly with saline water will not prevent
Coronavirus infection (item 10). Another group which is less than one third of the people were not sure. This is probably due to the less knowledge the respondents have in the prevention of new Coronavirus. $\mathrm{WHO}^{16}$ asserts that there are inadequate evidence to prove that regular rinsing of the nose with saline water will make the Coronavirus stay away. The knowledge of the respondents in the current study contradicts with fact issued by $\mathrm{WHO}^{16}$ and coincides with the knowledge of the respondents in Saudi Arabia ${ }^{27}$.

This study shows that more than half of the respondents' view that Coronavirus can be transmitted anywhere regardless of climate (item 11) which is similar to the fact issued by $\mathrm{WHO}^{16}$ that states Coronavirus can be spread in hot and humid temperatures. According to the view of researchers of the current study, this could be due to the broadcasting done by the government of South Africa. The findings of the current study are similar to the findings of the study conducted in India ${ }^{26}$.

More than half of the participants in this study had a perception that taking a hot bath will not prevent Coronavirus infection (item 12 ). $\mathrm{WHO}^{16}$ posits that it is dangerous to take bath in hot water which will not protect from Coronavirus. In comparison with a study conducted by Lui et al. ${ }^{28}$ to measure the knowledge of medical and nursing students on Human Immunodeficiency Virus (HIV) in Fiji an Island Country in Melanesia, the high majority of the students believed in the fact that HIV will transmit if a person takes a bath in a hot tub with an HIV patient which articulates that taking a hot bath will not prevent from HIV. Participants of the current study may have visited WHO and government health department websites to acquire the correct knowledge.

The minority of the people believed that holding breath for 10 seconds or more without coughing means that a person is free from Coronavirus (item 13). $\mathrm{WHO}^{16}$ avers that breathing tests cannot confirm that a person does not have Coronavirus. This may be due to the good knowledge of the participants in the current study which is similar to the findings by Narayana et al. ${ }^{26}$.

Almost all of the participants believed that a person who is infected with Coronavirus can recover from it (item 14). $\mathrm{WHO}^{16}$ states that the majority of the infected people have been recovered from COVID-19. A study conducted by Jalloh et al. ${ }^{29}$ to assess the knowledge of people in Guinea about Ebola Virus Disease shows that majority of the people were aware that they can recover from Ebola Virus. This is probably because that the participants in the current study were updating their knowledge from various trusted sources.

The study found that the age group of 18-25 years was significantly different from the age group of 26-35 years. The higher age groups such as 36-45 years, 46-55 years, 56-65 years and above 65 years were not statistically significantly differing from other age groups. A previous study conducted by Al-Hanawi et al..$^{30}$ in Saudi Arabia also shows that the higher age groups such as 30 39 years, $40-49$ years, $50-59$ years and above 59 years were statistically significant. 


\section{Conclusion}

By comparing the overall findings with the facts issued by WHO, it could be concluded that people in East London district of South Africa had good knowledge about SARS-Cov-2 on its transmission and what preventive measures that should be taken care of. However, some people were not sure on some of the myths and facts about the new Coronavirus such as whether eating garlic helps to prevent Coronavirus infection, antibiotics can be used as a treatment and rinsing nose regularly with saline water helps to prevent the Coronavirus infection. The findings also showed that there was a significant difference between the age groups of people on their knowledge about SARS-Cov-2.

\section{Limitations}

1. Respondents of this study were only from the East London district of South Africa. People from other regions of South Africa were not included in this study which can be considered as a limitation.

2. As the data was collected through an online survey, people who do not have smartphones or internet or enough network coverage might have been not able to participate in this study which can be considered as the second limitation.

3. People who cannot understand English, people who do not have minimal knowledge in using social media applications, people who do not have an email address, WhatsApp and other social media were not covered in this study.

4. The participants in the higher age group of 36-45 years, 4655 years, 56-65 years and above 65 years were less compared with younger age groups such as $18-25$ years and $26-35$ years which can be considered as another limitation.

5. Other socio-demographic data such as economic conditions and questions about handwashing were not included in this study.

6. Finally, as the URL was forwarded to the friends and families of the participants, the majority of the participants might be within their kinship or circle of friends.

\section{Recommendations}

Although the majority of the people had a high level of knowledge about SARS-CoV-2, very few people are sufficient to spread the virus to a greater extent. To avoid that, the health department and the government officials must conduct seminars and awareness programs in each and every location in the district about the new Coronavirus and how to prevent it as it is a deadly virus. WHO facts and myth busters must be circulated more than the current circulation through visual media, print media and by displaying posters on hoarding board on the roadsides and highways to bring awareness to all people about SARS-CoV-2.

\section{Implications}

The findings from this study will help the government and Health department to understand the level of knowledge of people about Coronavirus and to insist the health officials for conducting awareness programs to clear the misconceptions among the public. Furthermore, it would be beneficial to conduct a research that compares the results of this study with the knowledge of people in other selected African countries.

\section{REFERENCES}

1. Huang C, Wang Y, Li X, Ren L, Zhao J, Hu Y, et al. Clinical features of patients infected with 2019 novel coronavirus in Wuhan, China. Lancet. 2020;395(10223):497-506. https://doi.org/10.1016/S0140-6736(20)30183-5

2. Holshue ML, DeBolt C, Lindquist S, Lofy $\mathrm{KH}$, Wiesman J, Bruce H, et al. First case of 2019 Novel Coronavirus in the United States. N Engl J Med. 2020;382:929-36. https://doi.org/10.1056/NEJMoa2001191

3. World Health Organization (WHO). Pneumonia of Unknown Cause - China. Available from: https://www.who.int/csr/don/05-january2020-pneumonia-of-unkown-cause-china/en/

4. World Health Organization (WHO). Coronavirus Disease 2019 (COVID-19): situation report, 46. Available from: https://apps.who. int/iris/handle/10665/331443

5. World Health Organization (WHO). Rolling updates on coronavirus disease (COVID-19). Available from: https://www.who.int/ emergencies/diseases/novel-coronavirus-2019/events-as-theyhappen
6. Ebrahim SH, Ahmed QA, Gozzer E, Schlagenhauf P, Memish ZA. Covid-19 and community mitigation strategies in a pandemic BMJ. 2020;368:m1066. https://doi.org/10.1136/bmj.m1066

7. World Health Organization (WHO). COVID-19 cases top 10000 in Africa. Available from: https://www.afro.who.int/news/covid-19cases-top-10-000-africa

8. National Institute for Communicable Diseases (NICD). First case of covid-19 coronavirus reported in SA. Available from: https://www.nicd.ac.za/first-case-of-covid-19-coronavirusreported-in-sa/

9. Republic of South Africa. National lockdown regulations: Covid-19. Available from: https://sacoronavirus.co.za/2020/03/26/nationallockdown-regulations/

10. Republic of South Africa. Update on Covid-19. Available from: https://sacoronavirus.co.za/2020/05/29/update-on-covid-19-29thmay-2020/

11. Islam S. Coronavirus: One month after the first patient was identified, where does Bangladesh stand? Available from: https:// www.bbc.com/bengali/news-52207223 
12. Chirwa GC. "Who knows more, and why?" Explaining socioeconomic-related inequality in knowledge about HIV in Malawi. Sci African. 2020;7:e00213.

https://doi.org/10.1016/j.sciaf.2019.e00213

13. Chirwa GC, Sithole L, Jamu, E. Socio-economic Inequality in Comprehensive Knowledge about HIV in Malawi. Malawi Med J. 2019;31(2):104-11

https://doi.org/10.4314/mmj.v31i2.1

14. World Health Organization (WHO). WHO Director-General's opening remarks at the media briefing on COVID-19. Available from: https://www.who.int/director-general/speeches/detail/whodirector-general-s-opening-remarks-at-the-media-briefing-oncovid-19---5-june-2020

15. Manabe T, Hanh TT, Lam DM, Van DTH, Thuy PTP, Huyen DTT, et al. Knowledge, attitudes, practices and emotional reactions among residents of avian influenza (h5n1) hit communities in Vietnam. PLoS One. 2012;7(10):e47560.

https://doi.org/10.1371/journal.pone.0047560

16. World Health Organization(WHO). Coronavirus disease (COVID-19) advice for the public: Mythbusters. Available from: https://www. who.int/emergencies/diseases/novel-coronavirus-2019/advicefor-public/myth-busters

17. Nahar N, Paul RC, Sultana R, Gurley ES, Garcia F, Abedin J, et al. Raw Sap Consumption Habits and Its Association with Knowledge of Nipah Virus in Two Endemic Districts in Bangladesh. PLoS One. 2015;10(11):e0142292.

https://doi.org/10.1371/journal.pone.0142292

18. Aghababaeian $H$, Ahvazi LA, Ostadtaghizadeh $A$. The Methanol Poisoning Outbreaks in Iran 2018. Alcohol Alcohol. 2019;54(2):128-30. https://doi.org/10.1093/alcalc/agz005

19. Trew B. Coronavirus: Hundreds dead in Iran from drinking methanol amid fake reports it cures disease. Available from: https://www. independent.co.uk/news/world/middle-east/iran-coronavirusmethanol-drink-cure-deaths-fake-a9429956.htm

20. Liu X, Baecker A, Wu M, Zhou JY, Yang J, Han RQ, et al. Raw Garlic Consumption and Risk of Liver Cancer: A Population-Based Case-Control Study in Eastern China. Nutrients. 2019;11(9):2038. https://doi.org/10.3390/nu11092038

21. Arreola R, Quintero-Fabián S, López-Roa RV, Flores-Gutiérrez EO, Reyes-Grajeda JP, Carrera-Quintanar L, et al. Immunomodulation and Anti-Inflammatory Effects of Garlic Compounds. J Immunol Res. 2015;2015:401630. https://doi.org/10.1155/2015/401630
22. Alyami HS, Orabi MAA, Aldhabbah FM, Alturki HN, Aburas WI, Alfayez Al, et al. Knowledge about COVID-19 and beliefs about and use of herbal products during the COVID-19 pandemic: a cross-sectional study in Saudi Arabia. Saudi Pharm J. 2020;28(11):1326-32

https://doi.org/10.1016/j.jsps.2020.08.023

23. World Health Organization (WHO). Information note on HIV and COVID-19. Available from: https://apps.who.int/iris/ handle/10665/331919

24. Hoxha I, Malaj A, Kraja B, Bino S, Oluka M, Marković-Peković V, et al. Are pharmacists' good knowledge and awareness on antibiotics taken for granted? The situation in Albania and future implications across countries. J Glob Antimicrob Resist. 2018;13:240-5. https://doi.org/10.1016/j.jgar.2018.01.019

25. Iliyasu G, Ogoina D, Out AA, Dayyab FM, Ebenso B, Otokpa D, et al. A Multi-Site Knowledge Attitude and Practice Survey of Ebola Virus Disease in Nigeria. PLoS One. 2015;10(8):e0135955. https://dx.doi.org/10.1371\%2Fjournal.pone.0135955

26. Narayana G, Pradeepkumar B, Ramaiah JD, Jayasree T, Yadav DL, Kumar BK. Knowledge, perception, and practices towards COVID-19 pandemic among general public of India: A crosssectional online survey. Curr Med Res Pract. 2020;10(4):153-9. https://doi.org/10.1016/j.cmrp.2020.07.013

27. Alqrache AT, Mostafa MM, Atta HM. Knowledge and attitude towards covid-19 among students of king Abdulaziz University. Era's J Med Res. 2020;7(1):21-9. https://doi.org/10.24041/EJMR2020.4

28. Lui PSC, Sarangapany J, Begley K, Coote K, Kishore K. Medica and nursing students perceived knowledge, attitudes, and practices concerning Human Immunodeficiency Virus. Int Scholarly Res Not. 2014;975875. https://doi.org/10.1155/2014/975875

29. Jalloh MF, Robinson SJ, Corker J, Li W, Irwin K, Barry AM, et al. Knowledge, Attitudes, and Practices Related to Ebola Virus Disease at the End of a National Epidemic - Guinea, August 2015. MMWR Morb Mortal Wkly Rep. 2017;66(41):1109-15. http://dx.doi.org/10.15585/mmwr.mm6641a4

30. Al-Hanawi MK, Angawi K, Alshareef N, Qattan AMN, Helmy, HZ, Abudawood $Y$ et al. Knowledge, Attitude and Practice Toward COVID-19 Among the Public in the Kingdom of Saudi Arabia: a cross-sectional study. Front Public Health. 2020;8(217):1-10. https://doi.org/10.3389/fpubh.2020.00217 